\title{
РОЛЬ И ЗНАЧЕНИЕ КОНТРОЛЯ ДВИЖЕНИЯ ОСНОВНЫХ СРЕДСТВ В ГОСУДАРСТВЕННЫХ УЧРЕЖДЕНИЯХ
}

\author{
(C) 2020 Петров Александр Михайлович \\ доктор экономических наук, профессор Департамента учета, анализа и аудита \\ Финансовый университет при Правительстве Российской Федерации, Россия, Москва \\ E-mail: palmi@inbox.ru
}

Контроль представляет собой систему мероприятий, которая позволяет своевременно выявлять недостатки в работе подразделений и причины их образования, а также мотивировать сотрудников предприятия на добросовестное выполнение своих должностных обязанностей. Кроме того, благодаря внутреннему контролю своевременно выявляются недостатки, скрытые резервы и риски, которым подвержено предприятие, и на основании полученных заключений проводятся необходимые мероприятия для совершенствования деятельности и ограничения рисков деятельности государственных унитарных предприятий.

Ключевые слова: задачи, инструментарий, контроль, кризисные ситуации, механизмы, подходы, проекты, расходы, реализация, средства, финансы, экономическая информация, эффективность.

Основные средства в государственных учреждениях могут составлять основную часть активов и поэтому должны подвергаться особому контролю со стороны, как самого учреждения, так и государственных надзорных органов. Одной из проблем, связанной с движением основных средств, является их отсутствие на балансе предприятия, либо в связи с их непринятием на учет из-за незавершенного документооборота, либо по причине того, что работы, связанные с монтажом основного средства не завершены, либо еще по каким-то другим причинам. Существуют три способа обнаружении и устранения данной проблемы в государственных учреждениях:

- организация инвентаризации;

- осуществление мероприятий внутреннего контроля;

- проведение процедур внешнего аудита.

Самым оперативным является внутренний контроль. Согласно статье 19 Закона 402-ФЗ, учреждение обязано осуществлять и организовывать внутренний контроль за совершаемыми фактами хозяйственной жизни [7].

Основными элементами для внутреннего контроля в государственных учреждениях считают:

- коммуникацию и информацию;

- контрольную среду;

- процедуры внутреннего контроля;

- оценку внутреннего контроля;

- оценку рисков.
В отличие от инвентаризации, мероприятия по внутреннему контролю проводят в любое время по решению руководителя учреждения. Чаще всего инвентаризацию проводят только раз в год для сдачи годовых бухгалтерских отчетов. Но если того требуют обстоятельства в учреждении возможна организация внеплановой инвентаризации по инициативе руководителя или сотрудников. Как пример организации внеплановой инвентаризации можно привести следующие ситуации:

- пожар, стихийные бедствия и другие экстремальные условия;

- смена материально ответственного лица;

- обнаружение факта злоупотребления, порти и хищения имущества учреждения.

Единый государственный реестр прав на недвижимое имущество - базовый государственный информационный ресурс, в котором содержатся сведения действительных и не действительных правах на недвижимое имущество, сведения о недвижимом имуществе и данные о владельцах.

Также имущество для принятия к учету должно отвечать следующим критериям: имущественные объекты обязаны быть в собственности (исключения описаны в главе 25 НК РФ) и должны приносить прибыль.

Но существуют и возможные риски, так как нормами законодательства РФ не установлена возможность принятия к учету объекта недвижимости при отсутствии акта приема-передачи. 
При ведении налогового и бухгалтерского учета основанием являются первичные документы. Для передачи объекта недвижимости (нежилых помещений) либо оформляется акт по форме № OC-1a «Акт о приеме-передаче здания (сооружения)», либо допускается оформление акта приема-передачи недвижимости по самостоятельно разработанной форме.

Акт подписывается постоянно действующей комиссией по поступлению и выбытию активов, утвержденной руководителем учреждения, с указанием их фамилий и инициалов, должностей.

Для принятия к учету основного средства создается утвержденный руководителем учреждения акт (накладная) приемки-передачи основных средств в соответствии с пунктом $38 \mathrm{Me}-$ тодических указаний (Приказ Минфина России от 13.10.2003 № 91н). На каждый инвентарный объект необходимо составить такой акт.

Составление первичных документов происходит в соответствии с формами, которые утвердил руководитель государственного учреждения, об этом говорится в части 4 статьи 9 Закона № 402-ФЗ. В части 2 статьи 9 Закона № 402-ФЗ установлены обязательные реквизиты, которые должны содержаться в первичных документах, а именно:

- дата составления документа;

- наименование документа;

- наименование экономического субъекта, составившего документ;

- описание факта хозяйственной жизни;

- величина натурального и денежного измерения факта хозяйственной жизни;

- указание единиц измерения;

- наименование должности лиц, совершивших сделку и ответственного за ее оформление;

- подписи лиц, предусмотренных п. 7, с указанием их ФИО.

Первичные учетные документы (бухгалтерская справка) в свою очередь считаются свидетельством о данных в налоговом учете в соответствии со статьей 313 Налогового кодекса РФ.

При принятии ОС к налоговому и бухгалтерскому учету составляются акт приема-передачи имущества (OC-1) и инвентарная карточка (OC-6).

При принятии к учету объекта основного средства, важно решить с какого промежутка времени начать уплачивать налоги. Учреждение не освобождается от уплаты налогов, если в налоговой базе по налогу на имущество не будут включены вновь принятое имущество. При условии, что недвижимое имущество не относится к объектам, на которые налоговая база определяется по кадастровой стоимости в соответствии со статьей 378.2 НК РФ, либо при условии, что кадастровая стоимость не известна, то в соответствии пунктом 1 статьи 375 НК РФ налоговая база по налогу на имущество учреждения рассчитывается как среднегодовая стоимость имущества, признанного объектом налогообложения и учитывается по его остаточной стоимости, рассчитанной по правилам ведения бухгалтерского учета, отраженным в учетной политике учреждения, если иное не установлено НК РФ.

Необходимо подготовить приказ о принятии основных средств к учету и вводу в эксплуатацию. Приказ подтверждает то, когда именно основное средство было введено в эксплуатацию.

Так же важно с целью налогообложения решить вопрос начисления амортизации. Согласно сроку полезного использования, имущество относится к одной из десяти амортизационной группе в соответствии с пунктом 1 статьи 258 Налогового кодекса РФ. При вводе в эксплуатацию бухгалтер самостоятельно определяет срок полезного использования имущества руководствуясь положениями статьи 258 НК РФ и ОКОФ.

Для отражения основного средства в учете, необходимо правильно определить стоимость этого основного средства. Если это уникальное основное средство, то рекомендуется привлечь независимую оценочную компанию.

Датой принятия к бухгалтерскому учету будет дата, когда объект готов к эксплуатации.

ПБУ «Учет основных средств» (далее - ПБУ 6/01) (Приказ Минфина России от 30.03.2001 № 26н) и Методические указания по бухгалтерскому учету основных средств (Приказ Минфина России от 13.10.2003 г. № 91н.) регулируют в бухгалтерском учете учреждения информацию об основных средствах.

Руководствуясь положениями перечисленных нормативно-правовых актов, можно сделать вывод о том, что основным средством признается актив, одновременно выполняющий условия пункта 4 ПБУ 6/01: имущество находится в состоянии пригодного для пользования им в деятельности учреждения. Важную роль играет дата ввода в эксплуатацию.

Обнаруженное во время внутреннего контроля, внешнего аудита или инвентаризации 
Таблица. Отражение в бухгалтерском учете обнаруженного в результате инвентаризации основного средства

\begin{tabular}{|c|c|c|c|}
\hline Дебет & Кредит & Сумма (руб.) & Содержание операции \\
\hline 101.XX & 401.10 & 56400,00 & Основное средство принято к учету \\
\hline
\end{tabular}

основное средство не отражать в бухгалтерском учете нельзя. Отражение в бухгалтерском учете представлены в таблице.

Закон о бухгалтерском учете указывает на обязанности экономическими субъектами проводить внутренний контроль совершаемых фактов хозяйственной жизни. Зачастую учреждения не могут себе позволить ни контрольноревизионный отдел, ни даже ревизора из-за относительно небольшого штата работников. Именно поэтому на главного бухгалтера возложены функции ревизора. Это происходит из-за того, что в должностные обязанности главного бухгалтера в соответствии с Квалификационным справочником должностей, утвержденным Постановлением Министерства труда России от 21.08.1998 № 37 (ред. от 27.03.2018), входит:
- контроль за правильностью и своевременностью составления первичной документации, оформлению хозяйственных операций;

- контроль за обработкой бухгалтерской учетной информацией и ее сохранности;

- помощь руководителю и другим управленческим службам по вопросам, связанным с бухгалтерским учетом и отчетностью, контролем и анализом хозяйственной жизнью учреждения [8].

Из этого следует, что в соответствии с должностными обязанностями главный бухгалтер обладает контролирующими функциями. Главный бухгалтер, либо его заместитель, выполняет функции контролера в организации и проведении внутреннего контроля, что, конечно, несколько противоречит самой сути контроля.

\section{Библиографический список}

1. Информация Минфина России № П3-11/2013 «Организация и осуществление экономическим субъектом внутреннего контроля совершаемых фактов хозяйственной жизни, ведения бухгалтерского учета и составления бухгалтерской (финансовой) отчетности».

2. Бюджетный кодекс Российской Федерации от 31.07.1998 № 145-ФЗ (ред. от 27.12.2019 г.).

3. Бюджетный кодекс Российской Федерации от 31.07.1998 № 145-Ф3 (ред. от 27.12.2019 г.).

4. Уголовный кодекс Российской Федерации от 13.06.1996 г. № 63-ФЗ (в ред. 18.02.2020 г.).

5. одекс Российской Федерации об административных правонарушениях от 30.12.2001 № 195 -ФЗ (в ред. от 18.02.2020).

6. Федеральный закон от 05.04.2013 г. № 44-Ф3 «О контрактной системе в сфере закупок товаров, работ, услуг для обеспечения государственных и муниципальных нужд» (в ред. от 27.12.2019 г.).

7. О бухгалтерском учете: Федеральный закон от 06.12.2011 г. № 402-ФЗ.

8. Постановление Минтруда РФ от 21.08. 1998 г. № 37 (ред.27.03.2018 г.) «Об утверждении Квалификационного справочника должностей руководителей, специалистов и других служащих»

9. Бабаев Ю.А., Друцкая М.В., Кеворкова Ж.А., ЛистопадЕ.Е., Петров А.М. Бухгалтерский учет, анализ и аудит внешнеэкономической деятельности / учебник для студентов обучающихся по специальности 080109 «Бухгалтерский учет, анализ и аудит» / под редакцией Ю.А.Бабаева. Москва, 2010.

10. Петров А.М., Мельникова Л.А. Теоретические аспекты учета калькулирования себестоимости продукции / Экономические науки. 2013. № 102. С. 145-148.

11. Kevorkova Z.A., Petrov A. M., Savina N. V. Towards Liabilities Of Corporate Systems / International Journal of Civil Engineering and Technology. 2019. T. 10. № 2. C. 1582-1593.

12. Lymar M.P., Kevorkova Z. A., Petrov A.M. The Convergence Of National And International Accounting Standards: Chinese Experience / International Journal of Civil Engineering and Technology. 2018. T. 9. № 13. C. 82-94.

13. Петров А.М., Коняхин А.Н. Учетная политика при подготовке первой отчетности согласно МСФО / Международный бухгалтерский учет. 2013. № 11 (257). С. 2-15.

14. Petrov A.M., Sembieva L.M. ORGANIZATIONAL AND METHODICAL MECHANISM OF INTERNAL AUDIT OF SETTLEMENTS IN CORPORATE SYSTEMS / Bulletin of the National Academy of Sciences of the Republic of Kazakhstan, Volume 2, Number 384 (2020), 119-127, 2020 